\title{
Study on the Architecture Teaching Reform under the Sustainable Developmental Context
}

\author{
Yanqi CUI \\ Urban Construction Department \\ Zhongkai University of Agriculture and Engineering \\ Guangzhou, China \\ e-mail: 1328313514@qq.com
}

\author{
Yingde CUI \\ Guangzhou Vocational College of Science and Technology \\ Guangzhou, China \\ e-mail: cuiyingde@139.com
}

\begin{abstract}
Since the architect Paola Solerl put forward the idea of the Ecological Architecture in 1963. The theory and application of the sustainable building had been gradually developed in the world. In order to cultivate comprehensive architecture talents to meet the demand of the development of the sustainable building, many educationists in the universities have made a great effort on the architecture teaching reform. This paper starts with the analysis and summary of the current situation of architecture teaching reform in the domestic and international countries. Then it puts forward to the architecture teaching reform of the undergraduate students (five years) in architecture major that includes design concept and knowledge point reform, curriculum system reform, teaching methods reform and practice reform and provides some advice on them.
\end{abstract}

Keywords-architecture education; teaching reform; sustainable buildings;

\section{INTRODUCTION}

Building plays an important role in human exist and social development. It helps people to defend against the harsh nature environment and supplies the comfortable living and working space. However, it is also the major cause of energy shortage, ecological destruction and pollution. Based on the statistic, buildings consume $50 \%$ of the energy, $40 \%$ of the raw materials and $50 \%$ of the water resources. Moreover, it is responsible for $80 \%$ of the agricultural land loss and one-third of the $50 \% \mathrm{CO}_{2}$ emission $[1,2,3]$. Therefore, many architects have made great efforts on the sustainability of buildings recent years. As universities are the primary educational institutions of future architects and urban designers, it plays a significant role in promoting the sustainable development. The core of the architecture education should be adjusted to be the sustainable development of the environment and the society $[4,5]$. This paper discusses the teaching reform in the architecture courses under the sustainable concept.

\section{Current Situation of Architecture Teaching} REFORM IN THE DOMESTIC AND INTERNATIONAL COUNTRIES

Since the architect Paola Solerl put forward the idea of the "Ecological Architecture" in 1963, the theory and applications of the sustainable buildings had been gradually developed. Many universities and research institutes in the world have spared no effect on the sustainable architecture education. And some of them have set up the sustainable architecture department.

\section{A. Architecture Teaching Reform in International Countries}

In UK, the sustainable architecture education integrates the architectural design with the sustainable building technologies which is developed from the junior students in majority of the Architecture departments. The Architecture and Build Environment department of the University of Nottingham set up "sustainable architecture" course which has close links with environment, energy and sustainable development. The curriculum focuses on the architectural design studio, offering humanistic knowledge, science and technology these curriculum and series of lectures. The basic knowledge of sustainable buildings is the corn in "science and technology" course which is encouraged to be used in the design.

The curriculum of architecture department in the United States focuses on the architectural design studio as well. Most of the courses that the junior students take are the compulsory courses which emphasize on the study of basic knowledge, such as "Human and nature design", "Introduction to environmental design", enhancing the study on the theories of sustainable buildings. And the theoretical courses for the senior students are series of systematic and comprehensive optional courses whose core is knowledge deepen and the preparation of postgraduate study or professional career [7]. For example, the optional courses in sustainable building design in University of California, Berkeley are divided into preparatory course for junior students and courses for senior students. The curriculum covers the basic knowledge and technologies of sustainable buildings design, energy and environment, design practice, such as "Building Environment Science" course, "Sustainable building design" course, "Energy and environmental design strategy" course, providing students with a more comprehensive and systematic learning environment to study the relevant knowledge of sustainable buildings [8].

\section{B. Architecture Teaching Reform in China}

"Sustainable and Environmental Design" is one of the key research fields of the Chinese University of Hong Kong whose school of architecture is the first department in universities to start the earliest studies. The scope of basic 
courses covers buildings and environmental science, such as sound, light, heat and ventilation of buildings, and the study of the users' comfort level. The research courses include "Tropical Architecture and environmental design", "simulation of building energy consumption", "Landscape and sustainable building development" and special case studies [9].

The eight top architectural schools in China also add some sustainable building design related courses to the original curriculum. Emphasizing on the training of sustainable building design skills, reforming new architectural education system which integrates the architecture design with the sustainable building design and adding more theoretical courses of sustainable building technologies to synchronize the design studio are the three main teaching reform approaches. Tsinghua University stresses on the ecological building studio which integrates the architectural design and the building construction. Tianjin University focuses on the integration of sustainable building design and computer simulation, provides seminars of "Environment and building technologies" and thematic curriculum design regularly [10].

\section{STRATEGIES OF ARCHITECTURE EDUCATION REFORM}

Sustainable architecture teaching reform is a mainstream of the architecture education in the world, it is important for Chinese universities to keep up with the pace of the European and USA Universities.

\section{A. Design Concept and Knowledge Point Reform}

The students in architecture department of universities will become architects in the future. Their design concept of architecture will determine the sustainability of the buildings and society. Therefore, the traditional idea of the architecture design has to be reformed during the university time. The students' sustainable building design concept could be developed by the knowledge point reform. The added knowledge points include sustainable building design theories and principles, sustainable building technologies and sustainable building analyze.

\section{B. Curriculum Reform}

Till now, the architecture programs are mainly training students to meet aesthetic and functional requirements of buildings. Even though there are some sustainable courses for the students for optional course in some universities they are not systematic and not satisfy the human sustainable development demands. Consequently, in order to achieve the building sustainable goal, sustainable courses should be reform according to the different grades. For the freshmen, they should learn the basic sustainable ides and theories to develop a better architecture concept and ecological concept, like the courses introduction to livable environment, introduction to building technologies. For the senior students, they should integrate the sustainable building technologies into the architecture design courses. For example, "Sustainable building materials", "Solar and sustainable buildings", these courses should be added to their curriculum.
One or two types of sustainable building analysis software, such as EnergyPlus, should be mastered. And more optional courses of sustainable buildings are added in the schedule which could satisfy the interests of different students. For instance, the students want to get a job in real estate developers could select sustainable residential community projects, the students want to work as urban planners could choose "sustainable urban city". For the graduates, they should be able to use all the relevant knowledge to complete the graduate design $[11,12]$. At the meantime, they work as interns in design institute, participating in the sustainable building design projects; hence they could grasp the theories through the assessment, management and operation of the projects.

\section{Teaching Method Reform}

Based on the demand of the students, the teaching methods of different grade should be different. For the first grade students, the main training goals are setting up the architecture concept and ecological concept. The regular teaching method is lecture. From the second grade, the students should join in the architectural design studio which combines lecture and design. Appropriate architecture competition could be selected as the students' design project, which could help them have better understanding of the hot issue in their study field and improve their creativity and group working ability. Moreover, series of lectures on special topic, sustainable building visiting and group discussion are added in the schedule. For the graduates, they should spend the first semester in design institutes as trainees to participate in the projects which comprises of sustainable contents.

\section{Pratice Reform}

Traditionally, the practices in architecture department are: Survey and mapping; Architecture cognition practice; Graduate design and so on. In the reform of this section, the sustainable building design knowledge should be learned during the practice. In the survey and mapping practice, the group discussion of the same type of sustainable buildings could be had. In the architecture cognition practice, the sustainable buildings could also be visited. In the graduate design, the sustainable building technologies are required to use in the projects or set up a group of graduate design on comprehensive sustainable building design projects for the students who will engage in this area in the future [13].

Sustainable architecture teaching reform should integrate the theories, technologies and concepts of sustainable buildings into the architecture education by different stages and levels. It should cover the whole undergraduate study. The current architectural knowledge system should be expand and adjust, combining the sustainable architecture theory with the architectural knowledge system as a whole, so that the students will integrate the "sustainability" into "architecture" in design and concept.

\section{SUMMARY}

The modern architecture education has been about 100 years which was from Bauhaus as origin [14]. And the 
ecological concept was put forward by Paola Solerl in 1963 [15]. The theory and application of sustainable buildings had been gradually developed in the world. Many universities in the world adjust and improve the architecture education in order to meet the demand of development of society. But overall, the current educational reform involved in sustainable architecture is relatively dispersive and insufficient deepen and widen. This paper summarizes and analyzes the current educational reform situation in China. Combining the requirement of the undergraduate students (five years) in architecture major, it discusses the educational reform that includes design concept and knowledge point reform, curriculum system reform, teaching methods reform and practice reform and provides some advice on them.

\section{REFERENCES}

[1] Brian Edwards, Sustainable Architecture, China Architecture \& Building Press, 2003.

[2] Adeel Waqas, Zia Ud Din. Phase change material(PCM) storage for free cooling of buildings- A review, Renewable and sustainable energy review, 18 (2013) 607-625.

[3] Ren Naixin, Jiang Wenjie, $\mathrm{Xu}$ Jia. The Design Concept and Technology of Low Carbon Building. Huazhong Architecture, 2010(9): 18-21.

[4] Lidi Huang, Wenyan Zhao, Zhimin Sun. Exploration of Teaching Refotm of Basic Architecture courses Based on Sustainable Development concept. Journal of Heilongjiang College of Education. 2010 (3).

[5] Hui Xin Tai, Si Ai Ying. Probing into Architecture of Sustainable Development. Journal of Zhejiang University of Technology. 2009(2).
[6] Dekun Zhong, Jing Cheng. The Thinking of Architecture Education under the Ecological and Sustainable Idea. Architectural Journal,China, 2007(1): 1-4.

[7] Qiang Zhou. Research on Professional knowledge system framework of Architecture integrate Green building concept . Jinan, Shandong University of Architecture and Engineering, 2014.

[8] Jing Huang, Shen Xu, Hui Liu, The Integration of Architectural Design with Architectural Technology:Analysis of and Inspirations from the Architectural Education in the UK and USA, New Architecture, 2014(1):144-147.

[9] Chao Ren, Zheng Tan, Enrong Wu, The research on the strategies of Hong Kong and archtectural education from the perspective of sustainable development, Achitectural Journal, 2012(9):101-103.

[10] Weiju Yang, Bin Xu, Zhaohan Wu, Inheritance, Development, Interdiscipline and Integration: A Study on the Green Building Education System of Southeast University, New Architecture, 2015(5):113-117.

[11] Yong Li Xu. On Humanistic Conceotion in Ecological Architecture Design Teaching. ShanXi Architecture, 2013(12): 243-244.

[12] Xiang Zhao,Xue Bai, Bin Cheng. Responding to National conditions, Coming Back to Basic Principles: Thinking about Teaching Reform of Modern Architecture Theory. Proceedings of Chinese Design Semenar of International Innovation Design and Management Forum 2010, 341-343.

[13] Lin Li, A Study on Teaching Mode in Architecture Major Based on Engineering Practic. Thesis Submitted to Jiejiang University for the Master Degree. 2013: 1-20.

[14] Xu wang. From Bauhaus to AA School - The Research of Western Modern Architecture Education. Thesis Submitted to Tianjin University for the Master Degree of Architecture. 2015: 1-10.

[15] Jiang Lu. Eueopean Low Carbon Architecture Development and Technology Application Research. Thesis Submitted to Hebei University of Technology for the Master Degree of Architecture. 2012: 16-17. 